\title{
A SECONDARY SCHOOL TEACHER'S EXPERIENCES AS A VICTIM OF LEARNER CYBERBULLYING
}

Suzanne Bester, Alfred du Plessis and Janetta Treurnich

Department of Educational Psychology, Faculty of Education

University of Pretoria

Pretoria, South Africa

suzanne.bester@up.ac.za; alfred.duplessis@up.ac.za; madritreurnich@ gmail.com

Suzanne E Bester, PhD

Department of Educational Psychology, University of Pretoria

Aldoel 2-2, Groenkloof Campus

C/O George Storrar Road \& Leyds Street

Pretoria, 0002, South Africa

Telephone: +27-12-420-3891

Fax: $\quad+27-12-420-5511$

Email: suzanne.bester@up.ac.za

Keywords: cyberbully, cyberbullying, cybervictim, denigration, learner, psychosocial characteristics, psychosocial risks, teacher 


\section{ABSTRACT}

This instrumental case study reports on the unique experiences of a secondary school teacher from Gauteng who was a victim of learner cyberbullying. This teacher experienced severe emotional distress, family stress, anxiety, anger, intense humiliation and loss of dignity as a result of cyberbullying. On a professional level he felt unsupported by his teachers' union, school management team and teaching authorities. Support from his family, his community and the opportunity to share his experience with other teachers influenced his resilience positively while taking action made him feel like a role model for other teachers. This study highlights the effects of aggression in schools and raises concern about school climate and the need for social emotional competence programmes for learners.

\section{INTRODUCTION}

Children today are exposed to various social networking sites and have unlimited access to the internet, chat rooms, and mobile phones (Badenhorst 2011; Cowie and Jennifer 2008). This exposure has significantly changed the way in which they communicate with their peers and other people. National and international studies on cyberbullying have focused mainly on cyberbullying between children and adolescents and the effect that it has on these young people's well-being. However more recent international studies have found that students also cyber-bully their teachers which indicates that cyberbullying has moved beyond a student-tostudent level to a student-to-teacher level (Association of Teachers and Lecturers (ATL) 2007; Minor, Smith and Brashen 2013; National Association of Schoolmasters Union of Women Teachers (NASUWT) 2012; Reddy, Espelage, McMahon, Anderman, Lane, Brown, Reynolds, Jones and Kanrich 2013; Smith 2007). 
A survey carried out by the ATL in the United Kingdom revealed that many teachers were targets of online abuse by their learners. According to this survey, $45 \%$ of the teachers received upsetting emails, $38 \%$ received unwelcome text messages while $15 \%$ of those who received such messages reported them to be threatening in nature (ATL 2007). NASUWT (2012) further found that teachers were subjected to sexist and racist remarks and their photos were distributed across the internet. Forty-two percent said that they had been victims of insulting comments and allegations of inappropriate behaviour with learners and had comments posted on social networking sites about their performance at school (NASUWT 2012). Among the social networks that were used by learners to abuse their teachers, $77 \%$ used Facebook, 21\% used rate my teachers.com, 6\% used Twitter, and 1\% used MySpace.

An extensive review of international and national literature regarding the experiences of teachers as victims of cyberbullying highlighted the following research hiatuses: International studies that were reviewed, reported on data collected by means of quantitative survey studies and to our knowledge no qualitative studies which utilised in-depth interview methodology exist. South African research on cyberbullying of teachers is very limited in comparison with international studies and few statistics are available (ATL 2007; Badenhorst 2011; Belsey in Bullying.org Canada Incorporated 2004; Burton 2010; Burton \& Mutongwizo 2009; De Wet 2012; Hinduja and Patchin 2007, 2013; Minor et al. 2013; NASUWT 2012; Reddy et al. 2013; Smith 2007; Willard 2007). This instrumental case study attempted to address these research hiatuses by reporting on the personal experiences of a secondary school teacher from Gauteng who was a victim of learner cyberbullying. The following research questions guided this study: What were the cyberbullying experiences of a secondary school teacher from Gauteng? How did cyberbullying affect the secondary school teacher? What types of cyberbullying did the secondary school teacher experience? What challenges did the 
secondary school teacher face as a victim of cyberbullying? How did the secondary school teacher overcome the challenges of being a victim of cyberbullying?

\section{Cyberbullying and school climate}

Violence and aggression in schools in the form of any type of bullying is closely associated with school climate and according to Thapa, Cohen, Guffey and Higgins-D'Alesandro (2013) research evidence suggest that a positive school climate, where learners feel connected to their school, is associated with reduced aggression and violence as well as bullying.

School climate refers to the quality and character of school life and it includes norms,

values and expectations that support teachers, learners and parents to feel safe on social, emotional and physical levels (Thapa et al. 2013). Schools where people are engaged and respected and where all members of the school community namely management, teachers, learners and parents work collaboratively towards a shared vision for their school and towards delivering accountable citizens, promotes learning efforts and has positive implications for teacher retention (Center for Social and Emotional Education (CSEE) and National Center for Learning and Citizenship (NCLC) 2009).

Conversely, acts of aggression and/or violence perpetrated by leaners, whether aimed at other learners or at teachers, and whether in physical form or cyber form, compromises the safety of leaners and teachers, influences teaching and learning activities and the school climate (Singh and Steyn 2013). Since schools have an important role to play in transforming societies and in nurturing future citizens it makes sense that schools should play a major role in addressing learner aggression and Singh and Steyn (2013) believe that schools can fulfil this role by including social and emotional learning programmes in their curricula. Learners who are self-aware, socially aware, who have the ability to make responsible decisions, whom can self-manage, have relationship skills and are emotionally competent, are less likely 
to engage in acts of aggression. Although social and emotional skills are currently addressed in the South African school curriculum in the subject Life Orientation, Myburgh and Poggenpoel (2009) believe that schools can do more to promote pro-social behavior and address aggression in learners.

Cyber space does not have to be an unsafe space for learners and teachers. In a school where there is a positive school climate, cyber space "can be a haven for positive discourse where youth can seek a safe, nurturing environment for behaviours that reflect and promote social responsibility and encourage caring and respectful interactions" (Cassidy, Jackson and Brown 2009, 384).

\section{Teachers' experience as victims of learner cyberbullying}

According to the NASUWT (2012), learner cyberbullying can have devastating effects on teachers' well-being, health, self-esteem, reputation, and career progression. Reddy et al. (2013) state that teachers who are constantly threatened and exposed to different forms of aggression from learners may experience serious professional, mental, and interpersonal difficulties including depression, anxiety, stress, psychosomatic symptoms, as well as poorer professional functioning, loyalty, commitment and apathy. Reddy et al. (2013) also argue that teachers who are bullied at school are at an increased risk of alcohol abuse, post-traumatic stress disorder, burnout, serious damage to their personal and professional relationships, and committing suicide.

According to Reddy et al. (2013) and Smith (2007), teachers reported that bullying incidents made them feel extremely unsafe at school. In some cases, the teachers were so overwhelmed by the cyberbullying act that they felt compelled to retire early or leave the teaching profession (Reddy et al. 2013; Smith 2007). According to the Cyberbullying Research Center (2013), learner cyberbullying can cause great embarrassment to a teacher as 
the comments and messages are usually placed in the public domain. Many teachers believe that their reputations are severely damaged and feel extremely hurt by cyberbullying (Cyberbullying Research Center 2013).

\section{Characteristics and possible psychosocial risks of the cyber victim}

According to Campfield (2006), certain personal and interpersonal characteristics may put individuals at risk of becoming cyber victims. Vandebosch and Van Cleemput (2008) maintain that individuals who are perceived as more powerful or stronger in real life are often targeted by cyber bullies. The anonymity of the mobile phone and the internet seem to empower those who would otherwise probably not become real-life bullies and those who were formerly victims of traditional bullying. The current literature on cyberbullying gives little attention to characteristics that may make teachers vulnerable to learner cyberbullying, probably because this is a new and under-researched phenomenon. According to De Wet's (2012) study on educator-targeted bullying several personal, institutional, and social risk factors can make teachers more vulnerable to targeting by learner cyber bullies.

The personal risk factors included being easily provoked or intimidated by the learners, being young teachers, and being teachers perceived to be too strict or too powerful making them unpopular with the learners (De Wet 2012). On an institutional level, risk factors included a lack of support for the victims from their own institutions as well as a lack of knowledge on how the perpetrators should be disciplined or reprimanded for their bullying behaviour (De Wet 2012). Lastly, the social risk factors included a disregard for teacher authority by the community, disrespect and aggressive attitudes towards teachers, and an unwillingness of parents to discipline their children (De Wet 2012). 


\section{RESEARCH METHODOLOGY}

An instrumental case study design was selected for the study. An instrumental case study uses a particular case to gain an in-depth understanding of a particular phenomenon in its real-life context with the aim of obtaining a profound understanding of the perceptions and experiences of a person, group, or organisation (Cohen, Manion and Morrison 2011; Yin 2009). The application of an instrumental case study design complemented the epistemology of the study, interpretivism, as it enabled us to gain an in-depth understanding of the very unique experiences of the participant who was a victim of learner cyberbullying (Rule and John 2011). The selection of the participant for this study was thus purposefully done based on the fact that he was a victim of learner cyberbullying. Demographically the participant is a 49 year old white male secondary school teacher, who had more than 10 years teaching experience at the time of the study. At the time of the cyberbullying incident he was teaching at what could be described as an affluent Afrikaans medium secondary school. The participant also had a leadership position in the managerial structure of the school. The participant was contacted telephonically to make an appointment to discuss the research and after an informed consent process agreed to participate in a semi structured-interview which was conducted at a neutral site outside the school environment.

The following questions were posed to the participant during the semi-structured interview: 1) Please share with us your experiences as a victim of cyberbullying, 2) How were you cyberbullied? 3) How did the cyberbullying you experienced affect you as a teacher? 4) What challenges did you experience as a victim of learner cyberbullying? 5) How did you overcome these challenges? 6) Is there anything else you would like to share with us about your experience as a victim of learner cyberbullying?

The interview was audio-recorded and transcribed. Observation was used during the semi-structured interview and provided important supportive information on the verbal and 
non-verbal behaviour of the participant (Cohen et al. 2011). The observations were documented in the form of field notes that captured specific incidents during the interview (Merriam 2009). These notes recorded non-verbalized patterns such as gestures, facial expressions, general body language, and bodily interactions (Angrosino and Rosenberg 2011). In combination with the data collection methods discussed previously, a research diary was kept to further enhance the trustworthiness of the study. The interview, field notes and researcher diary were transcribed and coded into themes and then examined and broken down into categories. The data analysis focused on the participant's subjective experiences and perceptions of having been a victim of learner cyberbullying. Thematic content analysis was used in the evaluation of key words, meanings, themes, and non-verbal messages obtained during the data collection process. Data were segregated, grouped, regrouped, and re-linked in order to unify meaning and explanation of the data (Grbich 2013).

The following steps were implemented during the data analysis as suggested by Creswell (2009). Step 1: Organising and preparing the data for data analysis, which included transcribing the semi-structured interview, and sorting and typing up the field notes as well as the observations that had been recorded in the researcher diary. Step 2: Reading through all the data in order to obtain a general sense of meaning. This helped me form a picture of how the participant viewed, understood, and experienced learner cyberbullying. Step 3: After reading through all the data, coding was used to make labels that highlighted different focus themes in the data. Step 4: The coding process was used to create a description of the setting, the participant, and the themes for analysis. Step 5: After the coding process, a description of the themes was provided for representation in the qualitative narrative; and Step 6: The data were interpreted through a process of inductive reasoning.

In order to enhance the trustworthiness and validity of the study, member checking was carried out (Creswell 2009, 2014). After completion of the data analysis, the participant was 
consulted during a follow-up interview to discuss the accuracy of the identified topics and themes. He was also given an opportunity to include additional information and to correct existing information in the course of the follow-up interview.

\section{FINDINGS AND DISCUSSION}

Six main themes emerged from the data namely: type of cyberbullying experienced, causes of cyberbullying, characteristics of cyber bullies, response to cyberbullying, outcomes after taking action, and results relating to protective factors. The six main themes and recursive literature review are discussed below.

\section{Type of cyberbullying experienced}

The participant in this study was a victim of denigration, a type of cyberbullying that commonly involves the posting and sending of digitally altered photographs portraying the victim in a sexualised or slanderous way (Badenhorst 2011). Two learners in his school used a computer program to alter a photograph of the participant in which he was portrayed in a sexual way leading to severe humiliation for him in front of the school and the community. According to Willard (2007) denigration is a popular type of cyberbullying behaviour used by children and adolescents to cyber-bully teachers.

The participant described his experience as follows:

When the incident happened to me where children, uhm, (looking down and rubbing his hands) took a picture of myself and of the principal and manipulated to portray us in a indecent manner by placing us next to each other naked while we are masturbating each other (observation - looked down).

The one [learner] produced the photo, and another [learner] distributed it. So he rigged it on his computer, which brought together two photos and then the head of me and the 
head of the principal on the two persons (look down and rubbing his hands) sitting naked next to each other and their hands on each other's genitals.

The intent with denigration is aimed at damaging that individual's reputation or interfering with the individual's friendships (Burton \& Mutongwizo 2009; Willard 2007). In most cases, false sexual orientation rumours are sent or posted often with devastating effects. In the following sections we discuss the effects of cyberbullying as experienced by this participant.

\section{Causes of cyberbullying}

The participant believed that society looked down on teachers and considered the teaching profession as less important than other professions. The participant said that because of society's view of teachers, learners and parents had a general lack of respect and consideration for teachers and their well-being. He believed that this often led to cyberbullying incidents and to learners thinking that they had the right to bully or victimize teachers and that they should overlook or expect this type of misbehaviour.

The position held by the teacher in society, differs dramatically from a few decades ago where he was a person of stature, knowledge, and experience who people looked up to and now that view and interpretation of the role of the teacher in society has changed dramatically.

In a study on the status of teacher morale in Australia, Mackenzie (2007) found Australian teachers considered the status of education and the teaching profession as lower than that of other professions. Mackenzie (2007) stated that the low status of teachers was due largely to the community's lack of understanding of what teaching entailed. People were generally

unaware of the pressure on and workload of teachers and believed that anyone could teach if they wanted to (Mackenzie 2007). Teaching children on a daily basis was considered easy 
and no more than slightly better than child care, thus leading to the low status accorded to the teaching profession (Mackenzie 2007).

The participant further believed that parents often reinforced such misbehaviour by not setting an example for their children and by not teaching them to take responsibility for their wrongful behaviour.

Remember, that type of behavior is reinforced by parents (pointing finger).

According to De Wet (2012), teachers are often targeted by learners who have a general disregard for teacher authority and whose parents have an aggressive and disrespectful attitude towards teachers. De Wet (2012) adds that this situation is often aggravated by parents who are unwilling to discipline their children or who retaliate against schools when their children are disciplined.

The participant also said that teachers' prominent position in schools made them (particularly principals and deputy principals) more vulnerable to learner cyberbullying.

This happens especially with prominent figures, such as the principal of a school. It could also be someone, but I think many times it is someone who actually stands up for what is right and wrong. Who often, um, motivate children during conversations to act correctly and who act value driven, can often be the target perhaps because they are more prominent. People like to put such a person in the spotlight.

De Wet (2012) states that teachers in high authority positions are frequently targeted by learners as they are often perceived as unpopular. Learners who wilfully bully or victimise their teachers are basically trying to disempower them (Kauppi and Pörhölä 2012). This point is also made in Vandebosch and Van Cleemput's (2008) study where they argue that individuals who are perceived as more powerful or stronger in real-life tend to be targeted by cyber bullies in order to exercise power over them. 


\section{Characteristics of cyber bullies}

The participant characterized cyber bullies as cowardly and arrogant and lacking accountability. He said that learner cyberbullying was a convenient, safe way for learners to target or victimize their teachers. He added that modern technology enabled cyber bullies to remain invisible to their victims, thus making cyberbullying a cowardly act.

Yes, it's cowardly man (louder tone). It's just that, it's cowardly. Quite cowardly. Because you are faceless and you do it (pointing). You know how easy it is to send a text message.

Belsey (in Bullying.org Canada Incorporated 2004), too, states that cyberbullying is a cowardly form of bullying because the cyber bully can easily hide behind the anonymity afforded by the internet. One of the most dangerous features of cyberbullying lay in the distance and anonymity afforded to the cyber bully by modern technology (Patchin and Hinduja 2006). It was emphasised that cyberbullying was not a face-to-face experience, which made it such a tempting form of bullying to use against vulnerable individuals such as teachers (Slonje and Smith 2008). Some personal factors that can make teachers vulnerable to cyberbullying are listed by De Wet (2012) as being easily intimidated by learners; being young, inexperienced teachers; and being teachers perceived as too strict or powerful. On an institutional and social level, risk factors include lack of knowledge on how to identify and discipline cyber bullies, disregard for teacher authority by the community, aggressive attitudes towards teachers, poor school policies on cyberbullying, and unwillingness of parents to discipline their children (De Wet 2012).

Cyber bullies are commonly characterised as having maladaptive self-esteem with features of narcissism and defensive self-enhancement associated with aggression (Campfield 2006). Several researchers have found them to be anti-social, domineering, arrogant, and often lacking in empathy for others and in remorse for their misbehaviour (Olweus 1996; 
Perren and Gutzwiller-Helfenfinger 2012; Veenstra, Lindenberg, Oldenhinkel, De Winter, Verhulst and Ormel 2005). Topcu, Yıldirm and Erdur-Baker (2013) state that cyber bullies tend to be rude, thoughtless, and arrogant, believing they will never be found out, caught, and punished for their misbehaviour.

\section{Response to cyberbullying}

On an emotional level the participant experienced serious emotional distress and anxiety following the cyberbullying incident as well as anger towards the learners who had cyberbullied him. The participant considered cyberbullying as one of the worst forms of defamation and humiliation, which was due not only to the content of the messages sent about him but also to the fact that this information was placed in the public domain for all to see. This made the cyberbullying so much more distressing and embarrassing to him as a male teacher, seriously harming his dignity, name, and reputation.

So, when something like this happens with a teacher it is much worse than when you are in an office job where there are three people. You work in a school where there are hundreds of children, not just children, but a community around the school. So when you are troubled and bullied, or slandered or what term you want to use, it is under the spotlight because there are so many more people that know about it...but my dignity is affected (touching chest)...

The participant believed that learner cyberbullying could have a negative effect on the teaching profession as it could undermine teachers' motivation and a positive teaching environment. This statement is supported by Hinduja and Patchin (2013) who argues that cyberbullying can be considered more demoralising to a teacher's well-being than traditional forms of bullying as it enables the cyber bully to extend the victim's humiliation to a wider audience. Learner cyberbullying can cause a great deal of pain to teachers, and the 
humiliation can force them to leave the profession or take early retirement (Hinduja and Patchin 2013).

The participant said how undeserving he was of what had happened to him.

Ifelt, I, what is the word? It's not...I was not deserving of this (shaking his head).

The participant's view is confirmed by results from NASUWT (2012) and Reddy et al. (2013) who reported that learner cyberbullying could have devastating effects on teachers' reputations causing them to feel undervalued, frustrated, unappreciated, and demoralised.

The participant responded to the cyberbullying by taking legal action against the bullies. He reported the incident to the police and opened a case of crimen injuria. After the police had investigated the incident, the learners were forced to do community service. The participant then decided to proceed with a civil case against the learners to claim for damages done to his dignity, good name, and reputation. The court ruled in favour of the participant and charged the learners with crimen injuria. The participant stated that it was a personal goal of his to set an example for other teachers and to stand up for his dignity and self-worth.

I decided but it is a golden opportunity to finally also, um, to say enough is enough... and to eventually make work of it, on the one hand, to first inform the chairperson of the Governing Body that I, uhm, was going to do something about bringing these children to justice.

In contrast to the participant's decision to take action against the learners who cyber bullied him, Türküm (2011) found that teachers frequently do not report bullying incidents or avoid seeking professional help because of the perceived shame of their exposure to such violence. In addition De Wet (2010) states that teachers often remain silent about bullying incidents because of criticism by principals and local community members for being weak.

The participant's verbalisations and non-verbal gestures during the interview indicated that he experienced great emotional distress as a result of the cyberbullying incident. He 
stated that cyberbullying can make a person feel angry, and it can also cause uncertainty, unease, and self-doubt.

You go through all the normal processes of anger, self-doubt and actually the fact that you are being ridiculed.

The following extract was taken from my field notes and observations to illustrate the participant's non-verbal expression of his emotional experience.

He would touch his chest when he spoke about himself, almost as if he wanted to emphasise the pain and shock that he felt about what had been done to him.

De Wet (2012) argues that teacher bullying may result in low levels of motivation and morale, mediocrity, and reduced loyalty. Teachers who are regularly exposed to bullying behaviour will most likely withdraw both emotionally and psychologically from social and professional activities to avoid further victimisation (De Wet 2014).

\section{Outcomes after taking action}

The study data reveal a number of positive and negative outcomes for the participant after his decision to take legal action against the learners. The positive outcomes included his belief that he had provided a service to the profession, that the experience of taking action had some personal worth or value for him, and that it made a valuable contribution to case law and suggestions for future strategies to prevent or intervene in cyberbullying incidents.

I think (looking down) the fact that I could see this as a crusade, to stand up for other teachers, meant a great deal to me.

The negative outcomes for the participant of taking legal action were disillusionment with the school system, negative career implications/ramifications, and family stress. The participant said that he did not receive any support from the school system during the cyberbullying incident, which led to his disillusionment with the school system. The decision to take legal 
action against the learners also had negative career implications and ramifications for the participant. He reported that his name, reputation, and career were negatively affected due to resentment and unfair labelling by the teaching community. He was considered by some colleagues as a controversial person for taking such drastic measures against the learners.

I did not have the support of the school governing body or school management, not even from the union..." I have since been for interviews for school principal but one person made the comment...but how are we going to market you to the community because you are such a controversial person.

De Wet (2014) states that teachers are often not supported by their school management or colleagues after the occurrence of bullying incidents and that some school managers actually cover up cases of teacher-targeted bullying for the fear of bad publicity. De Wet (2012) adds that learner bullies are rarely reprimanded for their misbehaviour as the process of expelling or suspending deviant learners in South Africa is considered too technical or time consuming by management teams.

Galand, Lecocq and Philippot (2007) state that teachers who experience supportive leadership from different community support groups and who foster supportive relationships with their colleagues are less likely to become victims of learner bullying. Support from principals can reduce the difficulties arising from teacher-targeted bullying and can promote teacher well-being, which can then impact positively on professional development (Galand et al. 2007).

The study results further indicate that the cyberbullying incident and the participant's decision to take legal action placed considerable stress on the participant's family.

Yes, see my child was a pupil at that school...but he experienced a great deal of pressure because children made comments because I took the children to court now and so on. So there was really only tension in this regard (look down). 
Wei, Gerberich, Alexander, Ryan, Nachreiner and Mongin (2013) state that the violence directed towards teachers can have serious effects on their families, and Reddy et al. (2013) argue that teachers who are bullied at school are at an increased risk of serious damage to their personal and professional relationships.

\section{Protective factors}

Several protective factors helped the participant remain motivated after the cyberbullying incident. These factors included his character strength and the support he received from his family and some members of the local community. The participant reported that his strongest personal strength was his strong personality, which enabled him to stand up for himself and face the problem head on.

But I have strong personality. I did not ask them for permission.

The support the participant received from his family and certain members of the community was also considered a strong protective factor that helped him decide to take legal action against the learners.

My wife said...you have the same rights as any other person. That motivated me a great deal to take a stand for all teachers.

Galand et al. (2007) state that social support can be both a protective factor against victimisation and a mediator in the victimisation-stress relationship. According to Galand et al. (2007), family and social support can act as a buffer against the adverse effects of negative life events on a person's well-being.

\section{CONCLUSION}

This study focused on a specific participant and a unique case, that is, a teacher who was a victim of learner cyberbullying and who, as a result of his victimisation, decided to take legal 
action against the cyber bullies. The study findings therefore reflect the experiences of the particular participant's unique situation. His perceptions and experiences of learner cyberbullying may differ from those of teachers in different contexts, thus limiting the generalisability of the data.

Further studies should consider larger samples to verify the findings of this study. New studies needed on learner cyberbullying are: Comparative case studies on secondary school teachers to determine their emotional and behavioural responses to learner cyberbullying, surveys of secondary school teachers representative of the South African population to determine the incidence of learner cyberbullying in secondary school contexts, studies on learners' motivations to cyber-bully teachers, studies on the factors and psychosocial characteristics that put teachers at risk of becoming targets of learner cyberbullying, studies on the relationship between the status of teachers in society and learner cyberbullying incidents, studies on the effectiveness of various preventative measures in limiting or containing learner cyberbullying incidents, studies on the support or lack of support that principals and governing bodies provide to cyber-bullied teachers, studies on the support or lack of support given by departments of education to cyber-bullied teachers and studies on support strategies that departments of education provide for cyber-bullied teachers.

This case study aimed at raising awareness among different role-players such as teachers, principals, departments of education, unions, communities, educational psychologists, and future researchers about the reality of learner cyberbullying and its potential negative effect on the emotional and professional well-being of teachers.

Society and educational authorities should be made fully aware of the problems faced by teachers within and outside the school context as demotivated teachers will have a detrimental effect on the success of the learning that takes place in schools. Teachers need support to cope with the emotional and professional challenges they face due to 
cyberbullying. This support should come from role-players such as educational authorities, communities, educational psychologists, unions, and departments of education. The support should take the form of educating teachers about cyberbullying, supporting them in dealing with this problem, and bringing cyber bullies to justice.

Steps should be taken to ensure the safety of teachers within and outside the school context. Society as a whole needs to be aware of the difficulties that teachers face on a daily basis. We trust that this study contributed to a clearer understanding of the experiences of a secondary school teacher victimised by learner cyberbullying and that it will provide useful information for dealing with the problem in future.

This study highlights the challenges communities face in addressing issues relating to school violence and school climate. It also highlights the importance of policies and practices regulating safety in schools to ensure productive learning environments and the need for social emotional development of learners. Schools and cyber space should be safe havens for all where mutual respect, empathy and collaboration between learners and teachers lead to engaged learning experiences. This case however suggests that there is still much work that needs to be done in transforming South African schools into positive spaces for learning.

\section{REFERENCES}

Angrosino, M; and Rosenberg, J. 2011. Observations on observation: Continuities and challenges. In The SAGE handbook of qualitative research (4th ed.), eds. N.K. Denzin and Y.S. Lincoln. Thousand Oaks, CA: Sage Publications, Inc.

Association of Teachers and Lecturers (ATL). 2007. The modern face of bullying. [Online] Available at: http://www.atl.org.uk/policy-and-campaigns/conference/conf07/bullyingreport-conference-07.asp (accessed on 20 October 2014).

Badenhorst, C. 2011. Legal responses to cyberbullying and sexting in South Africa. Centre 
for Justice and Crime Prevention (CJCP) 10: 1-20. [Online] Available at: http://www.cjcp.org.za/uploads/2/7/8/4/27845461/issue_paper_10.pdf (accessed on 1 November 2015).

Bullying.org Canada Incorporated. 2004. What is cyberbullying? [Online] Available at: http://www.cyberbullying.ca/pdf/Cyberbullying_Information.pdf $\quad$ (accessed on 18 November 2015).

Burton, P. 2010. Cyber aggression and violence among SA youth.

Burton, P; and Mutongwizo, T. 2009. Inescapable violence: Cyberbullying and electronic violence against young people in South Africa. Centre for Justice and Crime Prevention (CJCP $) \quad$ 8: 1-12. [Online] Available at: http://www.cjcp.org.za/uploads/2/7/8/4/27845461/issue_paper_8.pdf (accessed on 11 November 2015).

Campfield, D.C. 2006. Cyberbullying and victimization: Psychosocial characteristics of bullies, victims, and bully/victims. Ph.D dissertation. Missoula, MT: The University of Montana. [Online] Available at: http://scholarworks.umt.edu/etd/288/ (accessed on 11 November 2015).

Cassidy, W; Jackson, M; and Brown, K.N. 2009. Sticks and stones can break my bones, but how can pixels hurt me? Students' experiences with cyber-bullying. School Psychology International 30(4): 383-402.

Cohen, L; Manion, L; and Morrison, K. 2011. Research methods in education (7th ed.). London, UK: Routledge.

Cowie, H; and Jennifer, D. 2008. New perspectives on bullying: A guide for practitioners. Berkshire, UK: Open University Press.

Creswell, J.W. 2009. Research design: Qualitative, quantitative, and mixed methods approaches (3rd ed.). Thousand Oaks, CA: Sage Publications, Inc. 
Creswell, J.W. 2014. Research design: Qualitative, quantitative, and mixed methods approaches (4th ed.). Thousand Oaks, CA: Sage Publications, Inc.

Center for Social and Emotional Education (CSEE); and National Center for Learning and Citizenship (NCLC). 2009. The school climate challenge: Narrowing the gap between school climate research and school climate policy, practice guidelines and teacher education policy. White Paper presented at Education Commission of the States (ECS). [Online] Available at: http://www.schoolclimate.org/climate/documents/school-climatechallenge.pdf (accessed on 7 January 2016).

Cyberbullying Research Center. 2013. Teacher shames student in classroom after student bullies teacher on Twitter. [Online] Available at: http://cyberbullying.us/teachershames-student-in-classroom-after-student-bullies-teacher-on-twitter/ (accessed on 25 May 2014).

De Wet, C. 2010. Victims of educator-targeted bullying: a qualitative study. South African Journal of Education 30: 189-201. [Online] Available at: http://www.ajol.info/index.php/saje/article/viewFile/55481/43953 (accessed on 19 November 2015).

De Wet, C. 2012. Risk factors for educator-targeted bullying: A social-ecological perspective. Journal of Psychology in Africa 22(2): 239-243.

De Wet, C. 2014. Educators' understanding of workplace bullying. South African Journal of Education 34(1): Art. \#767, 16 pages. [Online] Available at: http://sajournalofeducation.co.za/index.php/saje/article/viewFile/767/405 (accessed on 19 November 2015).

Galand, B; Lecocq, C; and Philippot, P. 2007. School violence and teacher professional disengagement. British Journal of Educational Psychology 77: 465-477. 
Grbich, C. 2013. Qualitative data analysis: An introduction (2nd ed.). Thousand Oaks, CA: Sage Publications Ltd.

Hinduja, S; and Patchin, J.W. 2007. Offline consequences of online victimization: School violence and delinquency. Journal of School Violence 6(3): 89-112.

Hinduja, S; and Patchin, J.W. 2013. Social influences on cyberbullying behaviors among middle and high school students. Journal of Youth and Adolescence 42(5): 711-722.

Kauppi, T; and Pörhölä, M. 2012. School teachers bullied by their students: Teachers' attributions and how they share their experiences. Teaching and Teacher Education 28(7): 1059-1068.

Mackenzie, N. 2007. Teacher morale: More complex than we think? The Australian Educational Researcher 34(1): 89-104.

Merriam, S.B. 2009. Qualitative research: A guide to design and implementation. San Francisco, CA: John Wiley \& Sons, Inc.

Minor, M.A; Smith, G.S; and Brashen, H. 2013. Cyberbullying in higher education. Journal of Educational Research and Practice 3(1): 15-29.

Myburgh, C; and Poggenpoel, M. 2009. Meta-synthesis on learners' experience of aggression in secondary schools in South Africa. South African Journal of Education 29(4): 445-460. [Online] Available at: http://www.sajournalofeducation.co.za/index.php/saje/article/view/290/174 (accessed on 7 January 2016).

National Association of Schoolmasters Union of Women Teachers (NASUWT). 2012. Pupils using social media to bully teachers. [Online] Available at: http://www.nasuwt.org.uk/Whatsnew/NASUWTNews/PressReleases/PupilsUsingSocial MediaToBullyTeachers (accessed on 12 November 2015).

Olweus, D. 1996. Bullying at school: Knowledge base and an effective intervention program. 
Annals of The New York Academy of Sciences 794: 265-276.

Patchin, J.W; and Hinduja, S. 2006. Bullies move beyond the schoolyard: A preliminary look at cyberbullying. Youth Violence and Juvenile Justice 4(2): 148-169.

Perren, S; and Gutzwiller-Helfenfinger, E. 2012. Cyberbullying and traditional bullying in adolescence: Differential roles of moral disengagement, moral emotions, and moral values. European Journal of Developmental Psychology 9(2): 195-209.

Reddy, L.A; Espelage, D; McMahon, S.D; Anderman, E.M; Lane, K.L; Brown, V.E; Reynolds, C.R; Jones, A; and Kanrich, J. 2013. Violence against teachers: Case studies from the APA Task Force. International Journal of School \& Educational Psychology 1(4): 231-245.

Rule, P; and John, V. 2011. Your guide to case study research. Pretoria, South Africa: Van Schaik.

Singh, G.D; and Steyn, G.M. 2013. Strategies to address learner aggression in rural South African secondary schools. Koers - Bulletin for Christian Scholarship 78(3): Art. \# 457, 8 pages.

Slonje, R; and Smith, P.K. 2008. Cyberbullying: Another main type of bullying? Scandinavian Journal of Psychology 49(2): 147-154.

Smith, A. 2007. Cyber-bullying affecting 17\% of teachers, poll finds. The Guardian 19 January. [Online] Available at: http://www.theguardian.com/education/2007/jan/19/schools.uk (accessed on 18 May 2012).

Thapa, A; Cohen, J; Guffey, S; and Higgins-D'Alesandro, A. 2013. A review of school climate research. Review of Educational Research 83(3): 357-385.

Topcu, Ç; Yıldırım, A; and Erdur-Baker, Ö. 2013. Cyberbullying @ schools: What do Turkish adolescents think? International Journal for the Advancement of Counselling 
35(2): 139-151.

Türküm, A.S. 2011. Social supports preferred by the teachers when facing school violence. Children and Youth Services Review 33(5): 644-650.

Vandebosch, H; and Van Cleemput, K. 2008. Defining cyberbullying: A qualitative research into the perceptions of youngsters. CyberPsychology \& Behavior 11(4): 499-503.

Veenstra, R; Lindenberg, S; Oldenhinkel, A.J; De Winter, A.F; Verhulst, F.C; and Ormel, J. 2005. Bullying and victimization in elementary schools: A comparison of bullies, victims, bully/victims, and uninvolved preadolescents. Developmental Psychology 41(4): 672-682.

Wei, C; Gerberich, S.G; Alexander, B.H; Ryan, A.D; Nachreiner, N.M; and Mongin, S.J. 2013. Work-related violence against educators in Minnesota: Rates and risks based on hours exposed. Journal of Safety Research 44: 73-85.

Willard, N. 2007. Cyberbullying and cyber threats: Responding to the challenge of online social aggression, threats, and distress (2nd ed.). United States of America: Research Press.

Yin, R.K. 2009. Case study research: Design and methods (4th ed.). London, UK: Sage Publications, Inc. 